\title{
Inhibition of adenovirus multiplication by inosine pranobex and interferon $\alpha$ in vitro
}

\author{
ANNA MAJEWSKA ${ }^{l}$, WITOLD LASEK ${ }^{2}$, MICHAE JANYST ${ }^{2}$, GRAŻYNA MŁYNARCZYK ${ }^{1}$ \\ ${ }^{1}$ Chair and Department of Medical Microbiology, Medical University of Warsaw, Poland \\ ${ }^{2}$ Department of Immunology, Center of Biostructure Research, Medical University of Warsaw, Poland
}

\begin{abstract}
There are no specific antivirals designed for adenoviral infections. Due to many cases of adenovirus infections worldwide, epidemic nature of some types of adenoviruses, and growing number of patients with severe adenoviral infections resulting from dysfunction the immune system, the need for searching an effective and safe therapy is increasing. Inosine pranobex exerts antiviral effects which are both direct and secondary to immunomodulatory activity. In the present study we evaluated in vitro effect of inosine pranobex and interferon $\alpha(I F N-\alpha)$ on replication of $H A d V-2$ and $H A d V-5$. The effectiveness of inosine pranobex under these conditions has not been previously reported. In conducted study we reported that inosine pranobex reduced the titer of infectious HAdV-2 and HAdV-5 in vitro. Higher concentrations of IP strongly inhibited multiplication of viruses. Combination of inosine pranobex and IFN- $\alpha$ display higher efficacy than either treatment alone and suggest that both agents may increase therapeutic effectiveness without augmenting toxic effects. Combination index calculations showed that inosine pranobex and INF- $\alpha$ synergistically inhibit HAdV-2 and HAdV-5 titers in A549 cells.
\end{abstract}

Key words: adenovirus, antiviral drugs, inosine pranobex, interferon $\alpha$.

(Cent Eur J Immunol 2015; 40 (4): 395-399)

\section{Introduction}

Human adenoviruses are DNA viruses that can cause a broad range of clinical syndromes, including asymptomatic viremia, respiratory tract infections, ocular disease, gastroenteritis, diarrhea, and cystitis. In contrast to a mild disease observed in normal hosts, adenoviral infections in immunocompromised people tends to disseminate, and the virus is isolated from multiple body sites, including the lung, liver, gastrointestinal tract, and urine. In individuals with an impaired immune response, life-threatening adenovirus infections are common [1-3]. There are no specific antivirals designed for adenoviral infections. In patients with a suppressed or deficient immune system, administration of cidofovir can be a therapeutic option but the agent can cause serious side effects and is also expensive. The major side effect associated with cidofovir therapy is renal toxicity, so it is reserved only for severe cases. Currently, there is no vaccine to prevent adenovirus infections [2, 4]. Due to many cases of adenovirus infections worldwide, epidemic nature of some types of adenoviruses, the growing number of patients with an impaired immune system (e.g. transplant recipients and AIDS patients), the need for searching an effective and safe therapy is increasing $[1,3,5]$. It is well known that the immune system can be manipulated specifically by vaccination or non-specif- ically by immunomodulation. For many years, a diverse array of recombinant, synthetic, and natural immunomodulatory preparations for prophylaxis and treatment of various infections are available. Many of them augment the anti-infectious immunity, especially cellular immune response. The immune-based therapies in combination with e.g. interferons can be one of the valuable therapeutic options [6-10]. The immunostimulating properties of inosine pranobex (Isoprinosine, 9-[3R)-3,4-dihydroxy-5-(hydroxymethyl)oxolan-2-yl]-3H-purin-6-one: 4-acetamidobenzoic acid: 1-(dimethylamino)propan-2-ol) were well documented. Besides its immunomodulatory effect, this drug has also antiviral and antitumor properties. Inosine pranobex is a purine nucleoside that is involved in a wide variety of intracellular biochemical processes. The mechanism of action in the human body is still unclear but numerous studies have demonstrated that this drug inhibits viral replication and exhibits a pleiotropic effect $[9,11$, 12]. Inosine pranobex can augment the production of cytokines such as interleukin-1 (IL-1) and interleukin-2 (IL-2). It increases the production of interleukin 12 (IL-12), interferon $\gamma($ IFN- $\gamma$ ) and decreases interleukin-3 (IL-3) and interleukin-4 (IL-4) production in vivo. Inosine pranobex normalizes the cell-mediated immunity stimulating T-cell differentiation and stimulates differentiation of B-lympho-

Correspondence: Anna Majewska, PhD, Chair and Department of Medical Microbiology, Medical University of Warsaw, 5 Chalubinskiego Str., 02-004 Warsaw, Poland, e-mail: anna.majewska@wum.edu.pl 
cytes into plasma cells and enhances antibody production. Inosine pranobex potentiates neutrophil, monocyte, macrophage chemotaxis and phagocytosis, augments NK activity [11-15]. This immunomodulator has been found to be useful in the treatment of several viral diseases such as herpes simplex, herpes zoster, rhinovirus infections, influenza, genital warts, and EBV infection [11, 12]. In the past, there were attempts to use inosine pranobex for the treatment of immunopathological disorders, such as rheumatoid arthritis and alopecia aerate. A combination of inosine pranobex and interferon $\alpha$ (IFN- $\alpha$ ) appears to be effective treatment in subacute sclerosing panencephalitis (SSPE) - the persistent measles complication of the central nervous system $[11,16,17]$.

\section{Objective}

The aim of this study was to evaluate in vitro inhibition of HAdV-2 and HAdV-5 replication by inosine pranobex (IP) alone and in combination with IFN- $\alpha$.

\section{Material and methods}

\section{Compounds}

Inosine pranobex (Isoprinosine, IP) was kindly provided by Gedeon Richter (Poland). Shortly before experiments, stock solutions of IP were prepared in culture medium $(1.0 \mathrm{mg} / \mathrm{ml})$, filtered $(0.2 \mu \mathrm{m}$ pore size) (Filtropur S 0.2, Sarstedt, Germany), and adequate volumes of the stock solution were added to cell cultures to obtain final concentrations ranging from 50 to $800 \mu \mathrm{g} / \mathrm{ml}$. These concentrations of IP were found non-toxic in preliminary experiments. Interferon (IFN- $\alpha-2 a$ ) was purchased from Roche and used at final concentrations of 1000 and 2000 $\mathrm{IU} / \mathrm{ml}$. Doses of IFN- $\alpha$ were chosen based on studies of other authors [18].

\section{Viruses}

The viral strains used in this study were as follows: Human Adenovirus type 5 (HAdV-5); ATCC VR-5 and Human Adenovirus type 2, wild-type (HAdV-2) strain 72. Both adenoviruses were propagated on A549 cells. They were harvested when the cytopathic effect reached more than $95 \%$, by freezing $\left(-80^{\circ} \mathrm{C}, 10 \mathrm{~min}\right)$ and thawing (room temperature) the cell-culture flasks three times. The supernatant was cleared by centrifugation $(3000 \times \mathrm{g}$ for $5 \mathrm{~min})$ and stored at $-80^{\circ} \mathrm{C}$ for further use.

\section{Cell lines}

Cells of the A549 cell line (human lung adenocarcinoma epithelial cells, ATCC, CCL185) and HEp-2 (human larynx carcinoma, ATCC, CCL-23) maintained in Eagle's Medium Essential Medium (Biomed, Poland) containing
$10 \%$ fetal bovine serum (Gibco Life Technologies, UK) and $1 \%$ penicillin/streptomycin antibiotics (Gibco Life Technologies, UK). HEL 299 cells (primary human lung fibroblasts, ATCC, CCL-137) were cultured in Dulbecco's Modified Eagles Medium (D-MEM, Sigma-Aldrich, USA) containing $10 \%$ fetal bovine serum (Gibco Life Technologies, UK) and a mix of the antibiotic-antimycotic mentioned above. Each cell line was cultured at $37^{\circ} \mathrm{C}$ in a humidified atmosphere containing $5 \% \mathrm{CO}_{2}$.

\section{Cytotoxicity assay}

This test was performed using HEp-2, HEL 299 and A549 cells. The cytotoxic effect of IP (at doses of 50$800 \mu \mathrm{g} / \mathrm{ml}$ ) and IFN- $\alpha$ (at a concentration of 1000 and $2000 \mathrm{IU} / \mathrm{ml}$ ) was assessed visually using light, inverted microscopy Olympus CK2 (Olympus Corp., Germany) and by the MTT colorimetric assay. The assay determines the ability of viable cells to convert a soluble tetrazolium salt [3-(4,5-dimethylthiazol-2-yl)-2,5-diphenyltetrazolium bromide] (MTT) into an insoluble formazan precipitate [19]. Cells were incubated in flat-bottom 96-microwell plates $\left(2 \times 10^{4}\right.$ cells $\left./ 0.2 \mathrm{ml}\right)$. After incubation of cells for $24 \mathrm{~h}$, IP and/or IFN- $\alpha$ were added (at doses given above) and cultured further for 24 and $48 \mathrm{~h}$. In controls, the cells were cultured without any of the tested drugs. Absorbance values of examined samples were read spectrophotometrically at a wavelength of $490 \mathrm{~nm}$ on a reader (Reader 230, Organon Technica Turnhout, Belgium). All experiments were performed in triplicates.

\section{Antiviral assay}

Antiviral effects of IP and IFN- $\alpha$ were assessed in vitro by phenotypic assays. The antiviral activity of inosine pranobex was tested using a series of non-toxic concentrations (50-800 $\mu \mathrm{g} / \mathrm{ml})$ diluted in an assay medium. Interferon $\alpha$ was used at final concentrations: 1000 and $2000 \mathrm{IU} / \mathrm{ml}$. To investigate the antiviral activity, cell cultures in flat-bottom microwell plates $\left(2 \times 10^{4}\right.$ cells $\left./ 0.2 \mathrm{ml}\right)$ were infected with HAdV-2 and HAdV-5 (0.01 TCID 50/cell $)$ for $60 \mathrm{~min}$. at $37^{\circ} \mathrm{C}$. After the absorption of the virus, inoculum was removed and fresh culture medium containing IP, IFN- $\alpha$ or both agents was added. Next, the cells were incubated for $48 \mathrm{~h}$. The yield reduction assay (YRA), which evaluates the ability of the compounds to inhibit virus multiplication in cell cultures, was applied. The cytopathic effect of the virus was evaluated $48 \mathrm{~h}$ after infection of cultures with viruses by means of light, inverted microscopy. The Reed-Muench statistical method was used to determine the $50 \%$ end point $\left(\mathrm{IC}_{50}\right)$ which was the lowest concentration of the tested drugs that reduces the viral infections of the control to a $50 \%$. The antiviral effect was estimated according to the reduction of the adenovirus titer in the presence of compounds with the controlled one. TCID $_{50 / \mathrm{ml}}$ (median tissue culture infective dose) was calculated. 
TCID $_{50 / \mathrm{ml}}$ denotes the amount of a pathogenic agent that will produce pathological changes in $50 \%$ of cell virus-inoculated cultures.

\section{Statistical methods}

The Wilcoxon signed rank sum test was used to analyze differences between the IFN- $\alpha /$ IP-treated virus-infected cells and the control group in terms of efficacy to reduce the viral titer. A value of $p<0.05$ was considered as statistically significant. Drug interactions were examined by the method of Chou and Talalay. The combination index (CI) was calculated to determine whether the drugs synergize. Combination index $<1$ indicates synergism between the drugs, $\mathrm{CI}=1$ indicates additivity, and $\mathrm{CI}>1$ denotes antagonism [20].

\section{Results}

\section{Cytotoxicity assay}

In the present study, the cytotoxic effect of IP and IFN- $\alpha$ was assessed using three cell lines (A549, HEp-2, and HEL 299) exposed to different concentrations of each compound (IP: 50-800 $\mu \mathrm{g} / \mathrm{ml}$ and IFN- $\alpha$ : 1000 and 2000 $\mathrm{IU} / \mathrm{ml}$ ) for $48 \mathrm{~h}$. The cytotoxicity was evaluated microscopically and by the MTT assay. There were no morphological changes, as assessed visually, in cell cultures treated with either IP or IFN- $\alpha$. MTT cytotoxicity assay confirmed microscopic observations. The viability of cells in the presence of the tested compounds was higher than $95 \%$. Since both IP and IFN- $\alpha$ were nontoxic at all concentrations, $\mathrm{TC}_{50}$ (toxic drug concentration which caused the reduction of the viable cell number by 50\%) and SI (Selectivity Index; $\mathrm{CC}_{50}$ to $\mathrm{IC}_{50}$ value) were not calculated.

\section{Antiviral assay}

The effect of IP and IFN- $\alpha$ on reduction of HAdV-2 and HAdV-5 titers was investigated in A549 cell culture. Inosine pranobex reduced the titer of infectious HAdV-2 and HAdV-5 in vitro. Higher concentrations of IP strongly inhibited multiplication of viruses. A summary of the inhibitory effects of IP on virus replication in A549 cells is shown in Fig. 1.

When $1000 \mathrm{IU} / \mathrm{ml}$ IFN- $\alpha$ alone was added to cultures of HAdV-2- and HAdV-5-infected cells, only a weak antiviral effect was detected. Interferon $\alpha$ at a concentration of $2000 \mathrm{IU} / \mathrm{ml}$ caused about $2 \mathrm{log}$ reduction in titers of HAdV-2 and about $1 \log$ reduction in titers of HAdV-5 compared to that of the control. When examined adenoviruses were exposed to $800 \mu \mathrm{g} / \mathrm{ml}$ of IP, reduction in virus titers was more than $1.5 \mathrm{log}$ in comparison to the control (no exposure to IP). Enhanced antiviral activity was observed when infected cells were treated with IFN- $\alpha$ and IP simultaneously. The reduction of the average viral titers of

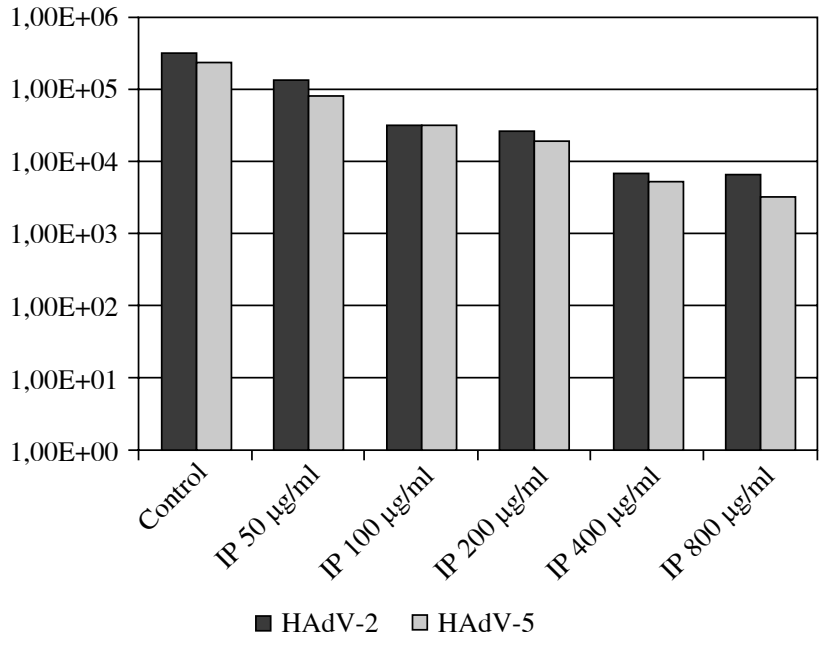

Fig. 1. Titer of the viral stock $\left(\mathrm{TCID}_{50 / \mathrm{ml}}\right)$ in cultures of HAdV-2 and HAdV-5-infected A549 cells incubated with inosine pranobex (IP)

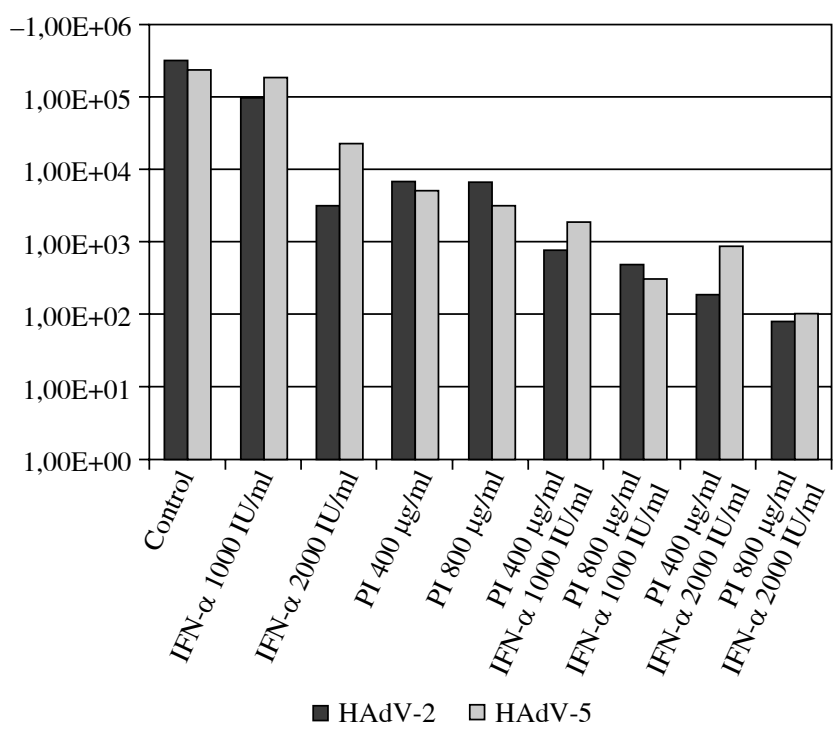

Fig. 2. Reduction of HAdV-2 and HAdV-5 titers in cultures of A549 incubated with inosine pranobex (IP) and/or interferon $\alpha$ (IFN- $\alpha)$

HAdV-2 and HAdV-5 in A549 cell culture after applying $800 \mu \mathrm{g} / \mathrm{ml} \mathrm{IP}$ and IFN- $\alpha$ (1000 IU/ml), in comparison to the viral titer in the control was reduced more than $2.5 \mathrm{log}$ (Student's $t, p<0.05)$. The increase in the dose of interferon to $2000 \mathrm{IU} / \mathrm{ml}$, still maintaining the concentration of $800 \mu \mathrm{g} / \mathrm{ml} \mathrm{IP}$, enhanced the inhibitory effect in the case of both viruses. The average HAdV-2 titer was reduced by about $2.0 \mathrm{log}$ and HAdV-5 titer was reduced more than $1.0 \mathrm{log}$ in comparison to the viral titer after exposure to IP $(800 \mu \mathrm{g} / \mathrm{ml})$ alone (Fig. 2) (Student's $t, p<0.05)$. Combi- 
Table 1. $\mathrm{IC}_{50}$ values after application of inosine pranobex (IP) and interferon $\alpha$ (IFN- $\alpha$ ), alone or in combination, in virus-infected cultures of A549 cells

\begin{tabular}{lcc}
\hline \multicolumn{1}{c}{ Virus } & HAdV-2 & HAdV-5 \\
\hline & $\mathrm{IC}_{50}[\mu \mathrm{g} / \mathrm{ml}]$ & \\
\hline $\mathrm{IP}(50-800 \mu \mathrm{g} / \mathrm{ml})$ & & 1304.5 \\
\hline $\mathrm{IC}_{50}$ & 1743.8 & $1678.0-1042.0$ \\
\hline $\mathrm{IC}_{50}(\mathrm{max} .-\mathrm{min})$. & $2591.1-1264.8$ & 694.8 \\
\hline $\mathrm{IP}(50-800 \mu \mathrm{g} / \mathrm{ml}) / \mathrm{IFN}-\alpha(1000 \mathrm{IU} / \mathrm{ml})$ & $1050.9-474.4$ \\
\hline $\mathrm{IC}$ & 963.2 & \\
\hline $\mathrm{IC}_{50}(\mathrm{max} .-\mathrm{min})$. & $1006.7-922.2$ & 683.1 \\
\hline $\mathrm{IP}(50-800 \mu \mathrm{g} / \mathrm{ml}) / \mathrm{IFN}-\alpha(2000 \mathrm{IU} / \mathrm{ml})$ & $927.1-512.1$ \\
\hline $\mathrm{IC}_{50}$ & 926.1 & \\
\hline $\mathrm{IC}_{50}(\mathrm{max} .-\mathrm{min})$. & $1044.0-825.4$ \\
\hline
\end{tabular}

nation of IP and IFN- $\alpha$ display higher efficacy than either treatment alone and may increase the therapeutic effect without augmenting toxic effects. Results are statistically significant for HAdV-2- and HAdV-5-treated A549 cell cultures simultaneously with $400 \mu \mathrm{g} / \mathrm{ml}$ and $800 \mu \mathrm{g} / \mathrm{ml}$ of IP and IFN- $\alpha$ (Wilcoxon signed-rank test, $p<0.05$ ).

The antiviral activity of the tested compounds was also analyzed on the basis of $\mathrm{IC}_{50}$ values (Table 1).

The $\mathrm{IC}_{50}$ value of IP against HAdV-2 was $1743.8 \mu \mathrm{g} / \mathrm{ml}$. The $\mathrm{IC}_{50}$ value of IP alone against HAdV-5 was $1304.5 \mu \mathrm{g} /$ $\mathrm{ml}$. When infected cells were treated with IFN- $\alpha$ and IP in combination, an enhanced antiviral activity was found. Application of IFN- $\alpha(1000 \mathrm{IU} / \mathrm{ml})$ with IP after infection of A549 cells with adenoviruses reduced the $\mathrm{IC}_{50}$ to $963.2 \mu \mathrm{g} /$ $\mathrm{ml}(\mathrm{HAdV}-2)$ and $694.8 \mu \mathrm{g} / \mathrm{ml}$ (HAdV-5). The combination of $2000 \mathrm{UI} / \mathrm{ml}$ of IFN- $\alpha$ and IP resulted in an even higher reduction of anti-adenoviral activity, by approximately $50 \%$. Finally, we reported that a combination of IP and IFN- $\alpha$ increases its antiadenoviral potency in vitro. Combination index calculations showed that IP and IFN- $\alpha$ synergistically inhibit HAdV-2 (CI: 0.80), and HAdV-5 (CI: 0.73) titers in A549 cells.

\section{Discussion}

Common occurrence of serious viral infections in both immunocompetent and immunocompromised patients and paucity of available antiviral drugs necessitate search for new treatment options [21-24]. One of them is searching new applications for currently available drugs and co-administration of them to elicit an additive or even synergistic effect $[22,25]$. The first antiviral therapies became available about 50 years ago. There are now more than 50 licensed antiviral compounds, half of them are used in the treatment of HIV infection. Hot topics in antiviral research are, besides HIV, HBV, HCV infections and in- fluenza $[21,26]$. The high cost and lengthy procedures of the drug discovery process are one of the major limiting factors in the development of new drugs. The fact that antiviral drugs are highly specific and are used for one single laboratory confirmed viral infections, significantly limits the number of diseases of commercial interest. Now, the pharmaceutical industry is not interested in the synthesis of new specific antiadenoviral drugs, so there are no possibilities for specific treatment in the near future [21, 25, 26].

Although little is known about the mechanism of action of IP, limited data have been published up to now on the bioassay and pharmacokinetics, but numerous studies have shown its ability to potentiate the cellular immune response both in vitro and in vivo experiments. Inosine pranobex was found to have a broad spectrum of antiviral activity, including reducing symptoms of human papillomavirus infection, genital herpes and some of viral respiratory infections $[9,11]$. Therefore, we decided to evaluate its effect in inhibiting the replication of adenoviruses. The effectiveness of IP under these conditions has not been previously reported. The available evidence indicates that IFN severely inhibits the replication of several viruses. Interferons are widely used for the treatment of chronic viral infections, mainly caused by hepatitis B virus and hepatitis $\mathrm{C}$ virus $[8,17]$. A combination of IFN- $\alpha$ and Isoprinosine has brought positive results in the treatment of a persistent and chronic encephalitis secondary to measles virus infection - subacute sclerosis panencephalitis (SSPE). Such combined therapy is still recommended because of theoretical synergistic effects $[11,16,17]$. In the conducted study we reported that IP reduced the titer of infectious HAdV-2 and HAdV-5 in vitro. Enhanced antiviral activity was observed when infected cells were treated with IFN- $\alpha$ and IP simultaneously. The combination of $2000 \mathrm{UI} / \mathrm{ml}$ IFN- $\alpha$ and IP resulted in reduction of anti-adenoviral activity, by approximately $50 \%$ in comparison to the control. Finally, we reported that IP and IFN- $\alpha$ synergistically inhibit HAdV-2 and HAdV-5 titers in A549 cells without augmenting toxic effects.

\section{Conclusions}

In the present study we demonstrated in vitro inhibition of HAdV-2 and HAdV-5 replication by IP and IFN- $\alpha$. Our findings have shown that a combination of IP and IFN- $\alpha$ display higher efficacy than either treatment alone and may increase the therapeutic effect without augmenting toxic effects. The effectiveness of IP under these conditions has not been previously reported. Hence, this application of IP and interferon warrants further investigation to confirm the inhibitory effect in vivo.

The authors declare no conflict of interest.

We would like to acknowledge the financial support of Gedeon Richter Polska Sp. z o.o. 


\section{References}

1. Hoffman JA (2009): Adenovirus infections in solid organ transplant recipients. Curr Opin Organ Transplant 14: 625633.

2. Lenaerts L, Naesens L (2006): Antiviral therapy for adenovirus infections. Antiviral Res 71: 172-180.

3. Tebruegge M, Curtis N (2010): Adenovirus infection in the immunocompromised host. Adv Exp Med Biol 659: 153-174.

4. Hoke CH Jr, Snyder CE Jr (2013): History of the restoration of adenovirus type 4 and type 7 vaccine, live oral (Adenovirus Vaccine) in the context of the Department of Defense acquisition system. Vaccine 31: 1623-1632.

5. Trojnar Z, Ciepiela O, Demkow UA (2014): The prevalence of IgG and IgA against adenoviruses in serum of children aged 11-26 months, hospitalised in the Clinical Paediatric Hospital in Warsaw Poland. Centr Eur J Immunol 39: 91-95.

6. Anlar B, Aydin OF, Guven A, et al. (2004): Retrospective evaluation of interferon-beta treatment in subacute sclerosing panencephalitis. Clin Ther 26: 1890-1894.

7. Mabley JG, Pacher P, Murthy KG, et al. (2008): The novel inosine analogue, INO-2002, protects against diabetes development in multiple low-dose streptozotocin and non-obese diabetic mouse models of type I diabetes. J Endocrinol 198: 581-589.

8. Kalliolias GD, Ivashkiv LB (2010): Overview of the biology of type I interferons. Arthritis Res Ther 12 Suppl 1: S1.

9. Mohamed TA (2014): Validated analytical method development of inosine pranobex in drug products by thin layer chromatography. Science 2: 59-66.

10. Schinazi RF, Cannon DL, Arnold BH, Martino-Saltzman D (1988): Combinations of isoprinosine and 3'-azido-3'-deoxythymidine in lymphocytes infected with human immunodeficiency virus type 1. Antimicrob Agents Chemother 32: 1784-1787.

11. Drews JF (1990): Immunostimulation. In: Immunopharmacology: Principles and perspectives. Drews JF (ed.). Springer-Verlag and Heidelberg, GmbH \& Co, Berlin; 201-285.

12. Campoli-Richards DM, Sorkin EM, Heel RC (1986): Inosine pranobex. A preliminary review of its pharmacodynamic and pharmacokinetic properties, and therapeutic efficacy. Drugs 32: 383-424.

13. Silvennoinen-Kassinen S, Karttunen R, Tiilikainen A, Huttunen K (1987): Isoprinosine enhances PHA responses and has potential effect on natural killer cell (NK) activity of uremic patients in vitro. Nephron 46: 243-246.

14. Petrova M, Jelev D, Ivanova A, Krastev Z (2010): Isoprinosine affects serum cytokine levels in healthy adults. J Interferon Cytokine Res 30: 223-228.

15. Lasek W, Janyst M, Wolny R, et al. (2015): Immunomodulatory effects of inosine pranobex on cytokine production by human lymphocytes. Acta Pharm 65: 171-180.

16. Gadoth N (2012): Subacute sclerosing panencephalitis (SSPE) the story of a vanishing disease. Brain Dev 34: 705711.

17. Gutierrez J, Issacson RS, Koppel BS (2010): Subacute sclerosing panencephalitis: an update. Dev Med Child Neurol 52: 901-907.

18. Mossman KL, Saffran HA, Smiley JR (2000): Herpes simplex virus ICP0 mutants are hypersensitive to interferon. J Virol 74: 2052-2056.

19. Pranczyk J, Jacewicz D, Wyrzykowski D, Chmurzynski L (2015): Platinum (II) and Palladium (II) Complex Com- pounds as Anti-cancer Drugs. Methods of Cytotoxicity Determination. Curr Pharm Anal 10: 2-9.

20. Chow TC, Talalay PP (1984): Quantitative analysis of dose-effect relationships: the combined effects of multiple drugs or enzyme inhibitors. Adv Enzyme Regul 22: 27-55.

21. De Clercq E (2002): Highlights in the development of new antiviral agents. Mini Rev Med Chem 2: 163-175.

22. Kumar V, Chandra S, Siddiqi MI (2014): Recent advances in the development of antiviral agents using computer-aided structure based approaches. Curr Pharm Des 20: 3488-3199.

23. Majewska A, Lasek W, Janyst M, Młynarczyk G (2016): In vitro inhibition of HHV-1 repication by inosine branobex and interferon- $\alpha$. Acta Pol Pharm Drug Res 2 (accepted for publication).

24. Mlynarczyk-Bonikowska B, Majewska A, Malejczyk M, et al. (2013): Antiviral medication in sexually transmitted diseases. Part I: HSV, HPV. Mini Rev Med Chem 13: $1837-$ 1845 .

25. Majewska A, Mlynarczyk-Bonikowska B, Malejczyk M, et al. (2015): Antiviral medication in sexually transmitted diseases. Part II: HIV. Mini Rev Med Chem 15: 93-103.

26. De Clercq E (2013): Dancing with chemical formulae of antivirals: A panoramic view (Part 2). Biochem Pharmacol 15: 1397-1410. 